UDC 811.111.161.2'25

DOI https://doi.org/10.32447/2663-340X-2021-9.7

\title{
LINGUOCULTURAL AND TRANSLATION ASPECTS OF ALLUSION FUNCTIONING IN MEDIA TEXTS
}

\author{
Vlasiuk Liudmyla Serhiivna \\ Master Student at the Department of Theory, Practice and Translation of the English Language, \\ National Technical University of Ukraine \\ "Igor Sikorsky Kyiv Polytechnic Institute" \\ Av. Peremohy, 37, Kyiv, Ukraine
}

Demydenko Olha Pavlivna

Candidate of Pedagogical Sciences,

Associate Professor at the Department of Theory, Practice and Translation of the English

Language,

National Technical University of Ukraine

"Igor Sikorsky Kyiv Polytechnic Institute"

Av. Peremohy, 37, Kyiv, Ukraine

\begin{abstract}
The article is devoted to the investigation of allusion phenomenon in the linguocultural and translation studies paradigm. This article is aimed at establishing the key ways of allusion's translation which are inextricably linked to its semantic and structurally functional features and cultural component. The theoretical framework for this article was provided on the basis of the analysis of the wide range of scientific papers written by both national and foreign researchers. As far as the illustrative material is concerned, the examples were taken from a great diversity of English newspapers and magazines. Allusion is considered to be one of the most complex phenomena in the modern linguistics. Despite the enormous variety of investigations aiming to provide the explanation for the allusion's controversial nature, it still remains poorly investigated with lots of issues open to discussion and further investigation. Nowadays allusion belongs to the most widely used devices in media texts, mainly due to its aim of exerting influence and imposing the necessary opinion on the reader. However, this extensive use of the stylistic device of allusion has given rise to the vast array of issues which are connected with its research and, consequently, provided a great impact for further investigations. Therefore, it is of the utmost importance to research allusion from the standpoint of both linguocultural and translation aspects taking into account its semantic and structurally functional features as well as the peculiarities of allusion's functioning in modern English media materials with the purpose of determining the most suitable methods of its translation into the Ukrainian language.
\end{abstract}

Key words: allusive unit, media text, linguoculturology, semantic and structurally functional features, allusion's functioning, translation transformations.

Problem statement and its relevance. The multidimensional nature of the allusion has not only made it one of the most widely used stylistic devices in modern English media materials, but it has also drawn extensive attention from scientists. Being a complex construct, which encompasses semantic, pragmatic and stylistic sides, allusion is being studied in diverse elective templates. With the study of allusion phenomenon the following disciplines are concerned: literary studies, stylistics, the theory of international communication, the theory of reference, communicative linguistics. However, allusion poses the biggest problem for linguocultural and translation studies since the issue of effective allusion translation into Ukrainian has always been acute. The key intractability lies in the fact that in the majority of cases it is too difficult to find the suitable equivalent, which will save the same effect as the original text. An allusion is indissolubly linked to the cultural component that is real historic events, personalities, literary works and so on, however, the reader does not always have the necessary amount of background knowledge to decipher the meaning of the allusion. That means that the problem of allusion translation becomes even more difficult. This explains the relevance of the investigation of the allusion phenomenon, in particular the issues of its translation since allusion remains insufficiently investigated, especially in the linguocultural and translation studies paradigm.

Analysis of the latest investigations and publications. Allusion phenomenon, the approaches 
to its study, criteria of allusion typology, its basic functions in different texts, peculiarities of allusion functioning in media texts as well as its linguocultural component have been the object of the research in the works of many scientists. Among them, we can distinguish the following works by S. R. Avramenko, O. O. Zabolotska, V. A. Maslova, O. O. Selivanova, M. Bell, U. Broich, and others. Many researchers have been engaged in studying the problem of allusion translation into the Ukrainian language. To those researchers belong K. V. Biletska, L. D. Burkovska, E. Shehloh, F. Beier and many other well-known scientists who made a significant contribution to the field of linguistics.

Purpose of the article and tasks. The purpose of the article is a linguistic investigation of semantic and structurally features of allusions and their functioning in media texts through the prism of linguocultural and translation aspects. The achievement of the purpose requires the execution of the following tasks: providing a rationale for the theoretical framework of the notion of allusion; establishing allusion functioning in media texts; investigating semantic and structurally features of allusion; researching allusion as a carrier of linguocultural information; determining key methods of allusion translation from English into Ukrainian.

Results and discussion. One of the characteristic features of modern publicistic style is the use of allusion - a special multidimensional stylistic device. Such a rapid spread of this device has turned massive attention of scientists to this phenomenon and its functioning in media materials. An allusion is a multi-faceted phenomenon and, therefore, it can be investigated from the standpoint of different approaches which may have translational, linguistic or linguocultural directions. As a rule, allusion is considered to be a language peculiarity, which refers to the historic or literary fact, but the notion of allusion is broader than the convoluted reference to a particular event $[1,4-5]$. The term "allusion" dates back to the XVI century. However, such studies were not popular at that time. Active investigations started in the XX century and entailed debates regarding the most accurate definition of the notion of allusion.

Scientists offer different definitions of the allusion notion. Usually, it is defined as a stylistic device, which comprises analogy or distinctive hint of any literary, historical, mythological or political fact that has engrained in the particular culture. However, most often allusion is defined through the prism of intertextuality as a type of intertext. Intertextuality is a text-discursive category, the realization of which occurs through the interaction of the text with semiotic universum. Thus, N. O. Fateieva defines allusion drawing on the notions of pretext and predication, which are the features of intertextuality. Predication is a combination of the implicit connotations in the text and the expression of the speaker's attitude to the reality that is to the text $[6,41-43]$. Pretext similar to the recipient text is a level, inside of which other context levels exist and the realization of the allusive unit can occur in both micro-context and macro-context. Hence the predication occurs - the combination of connotations: the connotation, which is enshrined in allusion's semantics, realizes in the context and combines with the connotations of other texts. Therefore, from the standpoint of intertextuality allusion - is a device, which enters the dialogic relations with texts (i.e. intertextual connections and connections with pretext and other texts).

Such a big amount of definitions of the notion of allusion can be explained by the great diversity of approaches to its study. The leading approaches are literary, cognitive, cognitively discursive, linguostylistic, semantic, pragmatic and linguocultural [5, 24-30]. Literary approach views allusion as a distinctive peculiarity of the writer's style. Therefore, the research of allusion is restricted by the study of literary tradition. The introduction of cognitive science to linguistic investigations has given rise to the advent of the cognitive approach to allusion's research. Within the cognitive approach, allusion is investigated by correlating the language form and mental functions. Quite popular nowadays is the cognitively discursive approach that was built upon the theory of conceptual integration and mental spaces. This approach studies allusion as an element, which realizes within the bounds of discourse and it cannot exist beyond its limits. The linguostylistic approach is closely connected with the investigation of allusion's linguistic and stylistic nature. Within the framework of this approach, allusion is interpreted as a deliberate use of words that refer to famous cultural facts. An allusion is viewed as a category of vertical context, method of text analysis, identification of the historically philological level of the reader's background knowledge. Within semantic and pragmatic approaches allusion is investigated as a special type of reference to the speech act. In these investigations, allusion is studied as a sign, an indication of the referent. Thus, according to C. Perri "allusions are divided into text elements and processes of their activation. The allusive unit has static and dynamic nature" [7, 118-120].

An allusion is of great value in the linguocultural studies paradigm for the researchers since the allusive unit is the essential source of 
information about the culture and mentality of the representatives of another linguocultural community. Allusion always encompasses information about important events and personalities of the past and present, which are culturally significant for the particular community $[3,75]$. Therefore, the allusive unit is a unique chest of certain ethnolinguistic communities. This can explain the importance of this approach as allusion transforms the culture into an integral part of the new text. Thus, allusion always reflects the so-called cultural component, which can be investigated from two perspectives: meaningful: it comprises three components (sender's culture and ideological competence that is author's value orientation which regulates the choice of precedent texts and the method of their transformation in allusive units; his professional excellence - author's language competence and his ability to act as a culture translator i.e. the ability to render precedent texts which reflect the cultural life; culture image of mass readership); functional: this perspective encompasses the following mechanisms: for sender's part - the application of his culture and professional excellence to create allusion; for receiver's part - the execution of the process of perceiving allusion and analyzing its meaning [3, 76-77]. Within the media, the text author encodes the information about events in the world in the form of allusion and the reader perceives and decodes allusive units.

Depending on the degree of explication allusive units can be of two types: explicit and implicit. Explicit allusions are available on the text's surface $[5,52]$. Allusive units of this type are well-known and, therefore, obvious: The magazine has a Herculean task: winning for the people of the world one of the most basic of human rights, the freedom of expression. In this example allusion refers to the famous myth about Hercules and, thus, the process of allusion's decoding doesn't require additional elements. Implicit allusions are converted and they're difficult to decode as the reader should possess solid background knowledge [5, 54]: Health activists have launched a flash mob with the symbolic name "Quitters". In this case, additional elements are needed to interpret the allusion's meaning. Thanks to the lexemes health, symbolic name and quitters, it becomes clear that the author has referred to Stephen King's short story "Quitters, Inc.".

However, the above-mentioned factors that are cultural components and allusion's degree of explication are not enough to achieve adequate translation. These features are closely connected with allusion's semantic and structurally functional features that also play a leading role in the process of the translation of allusive units. Semantic and structurally functional features of allusion depend on the special components which are present in the structure of any allusive unit: precedents and expresemes.

According to their semantic features allusions can be of the following types [4, 144-148]:

- homonymic: Ready to shine? The ball's in your door! Such allusions have in their structure elements which create formal oppositions with the components of the precedent text;

- synonymic: But you know the old saying "Better safe than sorrowful". Their antimarkers are in semantic oppositions with the precedents;

- antonymic: That's just one more example that in some cases adversity and loss make a man silly. Transformants of these allusions are antonyms with the denotations of the second order;

- hyper-hyponymic: Fruit a day keeps a doctor away: fruits with the highest vitamins content. Their transformants are either hyponyms or hyperonyms with precedents;

- extending: Kind Wizards of Tulsa place: how two best friends managed to fulfil the dreams of children from poor backgrounds. In this case, transformants introduce to allusion's structure additional components;

- restrictive: Body language and its secrets. What does a Cheshire smile can indicate? Antimarkers cross out of allusion's structure certain elements;

- inversive: Be slow in changing but slower in choosing: the importance of careful decision making. The transformants of such allusions are inversions.

Based on their structurally functional features the following types of allusions can be distinguished [6, 124-127]:

- detailing: All (even the hardest ones) roads lead to... Walmart! Why it is important to stop Walmart's store dominance? Such allusions introduce specific details to the content of the source text;

- metaphoric: Gone with elections: what happened to the money designated for the election campaign? Allusions of this type give the figurative meaning to the text;

- innovative: It doesn't look like our team is going to win this match but, anyway, run, Pittsburgh Steelers, run but don't stumble! These allusions substantially differ from the precedent text and add new elements that are absent in the original.

Cultural component, semantic and structurally functional features, allusion's degree of explication as well as the preservation of allusion's function in media text are important elements that need 
to be taken into account while translating the allusive unit into the Ukrainian language. Many investigations of both national and foreign researchers have been dedicated to this issue, however, the problem of the adequate and equivalent allusion translation belongs to one of the most acute problems in the linguistic circles [2, 42-46]. Let's look at a few examples of how allusive unit is translated into Ukrainian:

1) Who's the fairest of them all? New Miss World is already known. - Хто на світі всіх миліший, всіх рум'яніший й біліший? Ім'я нової «Міс Всесвіт» вже відоме. In this ехатple restrictive and metaphoric allusion is translated with the help of addition transformation;

2) Shameful people of the round table. After the government meeting, some inefficient reforms will wait for us. - Ганьбища круглого столу. Після засідання уряду на нас чекає ряд неефективних peфop. Here we see that innovative and extending allusion has been translated through functional equivalent and emphatization.

3) The Lord of the Rings and Jewels: Tiffany \& Co. has become the most popular jewelry brand in the world. - Володарка перснів та коштовних прикрас: ювелірна компанія «Tiffany \& Co.» стала найпопулярнішим брендом прикрас у світі. In this case detailing and extending allusion is translated with the help of concretization.

4) You can't expect honesty from politics. It's a complex game where Br'er Rabbit's style pays off. - Не варто очікувати чесності від політики. Це складна та заплутана гра, де хитросплетені діï приносять свої результати. According to its semantic and structurally functional features, this allusion is extending and metaphoric. Moreover, Br'er Rabbit has turned into the symbol of craftiness for English-speaking culture, therefore, the most suitable transformation is modulation.

5) Why isn't our government able to solve at least the most pressing issues? After all, they're not as intricate as Minotaur's Labyrinth? - Чому наш уряд не в змозі вирішити хоча б найбільш нагальні проблеми? Зрештою, вони не настільки хитромудрі як Лабіринт Мінотавра. Extending and detailing allusion is translated into Ukrainian through transformations of calque and transcription.

6) Maybe we need another Uncle Sam to revive patriotic feelings. - Можливо нам потрібен ще один типовий американський персонаж, який пробудить патріотичні почуття в населення. According to its semantic and structurally functional features allusion is restrictive and metaphoric. Furthermore, Uncle Sam is a popular character in American culture, but completely inexplicable for our culture. That's why the most appropriate method of translation is an explication and descriptive translation.

7) Falling down is not a failure but refusing to get back on your feet is. - Падіння - це не промах, промах - це відмова піднятися знову на ноги і продовжити боротьбу. In this example antonymic and detailing allusion is translated through grammatical substitution.

8) Take destiny into your own hands because fortune favours the bold. -Беріть долю в свої руки, адже сміливі завжди мають щцастя. Here synonymic and detailing allusion has been interpreted with the help of functional substitution.

9) Inner beauty is important. Find out why you shouldn't judge a book by its front page. Внутрішня краса важлива. Дізнайтеся, чому не варто судити книгу по обкладинці. In this case, hyper-hyponymic and detailing allusion is translated through the transformation of generalization and functional substitution.

The adequate and equivalent translation can be achieved with the help of special methods - the so-called translation transformations. However, the choice of transformation depends on many factors: type of allusion according to its semantic and structurally functional features, cultural component, context, degree of explication and allusion's function. The most widely used transformations belong to descriptive translation, explication, addition, functional substitution, grammatical substitution, functional equivalent, modulation, concretization, generalization and transcription.

Conclusions and scope for further research. Nowadays the leading approach to the study of allusion is its investigation within the linguocultural and translation studies paradigm as mentality and ethnolinguistic specificity of a particular community are enshrined in cultural codes. To decode allusion it is necessary to understand the source of its pretext and culture, which is connected with this pretext. Thus, the cultural component plays an extremely important role in the process of allusion translation. But the cultural component is not the only factor that is required to take into consideration while translating allusion. It is also of utter importance to pay attention to its semantic and structurally functional features, which influence its types. Although the investigations of allusion from the view of linguocultural and translation aspects have been carried out for years, these issues still offer a platform for further investigations. 


\title{
BIBLIOGRAPHY
}

1. Авраменко С. Р. Стилістичні функції алюзій. Гуманітарний вісник. 2007. № 11. С. 3-8.

2. Ананьїна М. А. Труднощі відтворення лінгвокультурної інформації при перекладі українською. Київ: Ранок, 2014. $97 \mathrm{c}$.

3. Гаріфуліна А. М. Алюзії як транслятори культурних кодів. Гуманітарний вісник. 2011. № 4. С. 74-80.

4. Заболотська О. О. Алюзія в художніх текстах: лінгвокогнітивний аспект. Науковий вісник Херсонського державного університету. 2011. № 13. С. 143-150.

5. Некряч Т. Є. Інтертекстуальна іронія та переклад. Київ: Карпенко, 2010. 176 с.

6. Фатеева Н. А. Интертекст в мире текстов: контрапункт интертекстуальности: монография. Москва: КомКнига, 2007. 280 c.

7. Perri, C. (1984) Knowing and Playing: The Literary text and Trope Allusion. American Imago, (41), 117-128.

\section{REFERENCES}

1. Avramenko, S. R. (2007). Stylistychni funktsii aliuzii [Allusion's stylistic functions]. Humanitarnyi visnyk, 11. S. 3-8 [in Ukrainian].

2. Ananina, M. A. (2014). Trudnoshchi vidtvorennia linhvokulturnoi informatsii pry perekladi ukrainskoiu [Difficulties of translation of linguocultural information into Ukrainian]. Kyiv: Ranok. $97 \mathrm{~s}$ [in Ukrainian].

3. Harifulina, A. M. (2011). Aliuzii yak transliatory kulturnykh kodiv. [Allusions as translators of cultural codes]. Humanitarnyi visnyk, 4. S. 74-80 [in Ukrainian].

4. Zabolotska, O. O. (2011). Aliuziia v khudozhnikh tekstakh: linhvokohnityvnyi aspekt [Allusion in literary texts: linguocognitive aspect]. Naukovyi visnyk Khersonskoho derzhavnoho universytetu, 13. S. 143-150 [in Ukrainian].

5. Nekriach, T. Ye. (2010). Intertekstualna ironiia ta pereklad [Intertextual irony and translation]. Kyiv: Karpenko. $176 \mathrm{~s}$ [in Ukrainian].

6. Fateeva, N. A. (2007). Intertekst v mire tekstov: kontrapunkt intertekstualnosti: monografiya [Intertext in the world of texts: counterpoint of intertextuality: monography]. Moskva: KomKniga. 280 s [in Russian].

7. Perri, C. (1984). Knowing and Playing: The Literary text and Trope Allusion. American Imago, 41, 117-128.

\section{ЛІНГВОКУЛЬТУРНИЙ ТА ПЕРЕКЛАДОЗНАВЧИЙ АСПЕКТИ ЯВИЩА АЛЮЗІЇ В МЕДІА МАТЕРІАЛАХ}

\author{
Власюк Людмила Сергіївна \\ магістранка кафедри теорії, практики та перекладу англійської мови \\ Начіонального технічного університету України «Київського політехнічного інституту \\ імені Ігоря Сікорського» \\ пр. Перемоги, 37, Київ, Украӥна
}

\author{
Демиденко Ольга Павлівна \\ кандидат педагогічних наук, \\ доцент кафедри теорії, практики та перекладу англійської мови \\ Начіонального технічного університету України «Київського політехнічного інституту \\ імені Ігоря Сікорського» \\ пр. Перемоги, 37, Київ, Украӥна
}

\begin{abstract}
Статтю присвячено вивченню явища алюзї в парадигмі лінгвокультурологічних та перекладознавчих досліджень, оскільки, на сьогодні, вивчення алюзії з позиції ичих підходів є одним із найгостріших питань серед вчених-лінгвістів. Метою статті є встановлення ключових способів відтворення алюзії, які нерозривно пов 'язані з ї̈ семантичними та структурно-функціональними особливостями, а також культурологічним компонентом. Теоретичною базою иього дослідження слугували численні праці вітчизняних та іноземних науковців, а приклади були взяті з англомовних газет та журналів. На сьогоднішній день, алюзія вважається одним із найскладніших явищ в сучасній лінгвістичі. Попри величезну кількість досліджень, які мали на меті надання пояснення суперечливої природи алюзї̈, вона ще й досі залишається маловивченою, адже велику кількість питань так $і$ не було закрито, а отже існує потреба подальшого вивчення иьього явища. Серед вчених-лінгвістів і досі точаться суперечки стосовно підходів до вивчення алюзії, ї̈ типологї та функцій. Зокрема, особливо гостро постало питання особливостей функціонування лінгвістичного явищза алюзії в медіа текстах, в тому числі проблема ї̈ відтворення в украӥнському перекладі. В сучасних медіа текстах алюзія є одним із найчастіше вживаних прийомів,
\end{abstract}


головним чином через ї̈ мету впливу та нав'язування необхідної думки читачеві. Таке иироке використання стилістичного прийому алюзї̈, в свою чергу, дало поштовх для подальших досліджень изього унікального явища. Втім, варто зазначити, щсо найскладнішу проблему, на сьогодні, становить питання відтворення алюзї в українському перекладі тому, щз переклад алюзії значною мірою залежить від культурологічного компоненту. Цим пояснюється необхідність вивчення алюзії з позииії як лінгвокультурного, так і перекладознавчого аспектів. При иьому необхідно враховувати семантичні та структурно-функиіональні особливості алюзії, ії функиіонування в сучасних англомовних медіа матеріалах, а також особливості мови перекладу з метою встановлення найбільш відповідних та коректних способів відтворення алюзійної одиниці в українському перекладі.

Ключові слова: алюзійна одиниця, медіа текст, лінгвокультурологія, семантичні та структурно-функиіональні особливості, функціонування алюзї, перекладаџькі трансформації. 